\title{
The Oak Lace Bug: Appearance and Distribution in Russia ${ }^{+}$
}

\author{
Yuri I. Gninenko ${ }^{1,2}$, Uliana A. Chernova ${ }^{1}$ and Vladimir P. Nalepin ${ }^{2}$ \\ 1 All-Russian Research Institute of Silviculture and Mechanization of Forestry, Pushkino, ul. Institutskaya 15, \\ Moscow oblast, Russia \\ 2 Russian State Agrarian University - Moscow Timiryazev Agricultural Academy, ul/ Timiryazeva, 49, Mos- \\ cow, Russia \\ * Correspondence: Yuri.Gninenko.2021@gmail.com \\ + Presented at the 1st International Electronic Conference on Entomology (IECE 2021), 1-15 July 2021; \\ Available online: https://iece.sciforum.net/.
}

Citation: Gninenko, Y.I.; Chernova, U.A.; Nalepin, V.P. The oak lace bug: appearance and distribution in Russia, in Proceedings of the 1st International Electronic Conference on Entomology, 1-15 July 2021, MDPI: Basel, Switzerland, doi:10.3390/IECE-10390

Published: date

Publisher's Note: MDPI stays neutral with regard to jurisdictional claims in published maps and institutional affiliations.

Copyright: (c) 2021 by the authors. Submitted for possible open access publication under the terms and conditions of the Creative Commons Attribution (CC BY) license (http://creativecommons.org/licenses /by/4.0/).

\begin{abstract}
The oak lace bug Corythucha arcuata was first discovered in Russia in Krasnodar in 2015.The first severe oak trees damage was revealed in the Krasnodar Krai in 2016.Since then, the spread of the C. arcuata has led to the fact that its population outbreaks have been observed in forests and landscaping with the participation of oak throughout from the Black coast to the coast of the Caspian Sea. Annually, the total area of damaged forests in Russia is about 1 million hectares. Chestnut-leaved oak Q. castaneifolia and pedunculate oak Q. robur are most severely damaged by C. arcu$a t a$, but the level of influence of such damage on the state of forests remains unknown.
\end{abstract}

Keywords: Corythucha arcuata; host plant; spread

\section{Introduction}

The oak lace bug Corythucha arcuata Say, 1832 (Hemiptera, Heteroptera: Tingidae) is widespread in North America, where it lives in oak trees of the United States and neighboring territories in the south-eastern part of Canada. After first discovery in Italy in 2000 [1], the rapid spread of C. arcuata began to be monitored in other European countries. And after C. arcuata was introduced in Turkey [2], its appearance in Russia was predetermined [3]. C. arcuata was first discovered in Russia in 2016 due to archival photographs of 2015 with one egg cluster on an oak leaf was found. Therefore, it is believed that the introduction of the bugs began in 2015. Due to the comparison of satellite images of oak forests in 2015 and 2016, severe damage to oak crowns was found, but this detection was not initially assessed by forest protection services as a real danger [4]. The rapid spread of the oak lace bug throughout Russia started. At that moment area of oak stands damaged by this invasive species was about 1.0 million hectares.

\section{Materials and methods}

The surveys were carried out in natural oak forests in 2018and in landscaping of several species of the genus Quercus in the southern regions of Russia. Checked for the presence of $C$. arcuata (adults, larvae, egg clusters) on oaks was carried out visually, carefully inspecting the lower branches of oaks, in the second half of summer, when chlorotic discoloration of leaves was clearly visible. The presence of C. arcuata was assessed on the following scale:

1 - pest absent (also no damage);

2 - the pest is very rare: few adults or larvae and egg clusters on several leaves have been identified;

3 - the pest is common: different developmental stages of C. arcuata are found on most leaves that can easily be spotted on the tree. 
4 - very common: C. arcuata individuals are found on most leaves in the crown in a large number. Heavily infested trees can be spotted very easily.

During route surveys, special attention was paid to finding the adults $C$. arcuata on oak trees. At the same time, the presence of at least one adult or larva of C. arcuata in this area means that the invader has already penetrated and infested this territory. Also, several pesticides were tested, the use of which will prevent the spread of bugs and reduce damage from ones. Tests were carried out by spraying of oak branches. The branches were cut, sprayed with insecticides, and on them placed adult bugs in a cages. Mortality was recorded on 3 or 5 days after.

\section{Results and discussion}

The first search surveys to check the presence of $C$. arcuata on oaks were carried out along the route from Rostov-on-Don to Makhachkala (№1) (Figure 1).

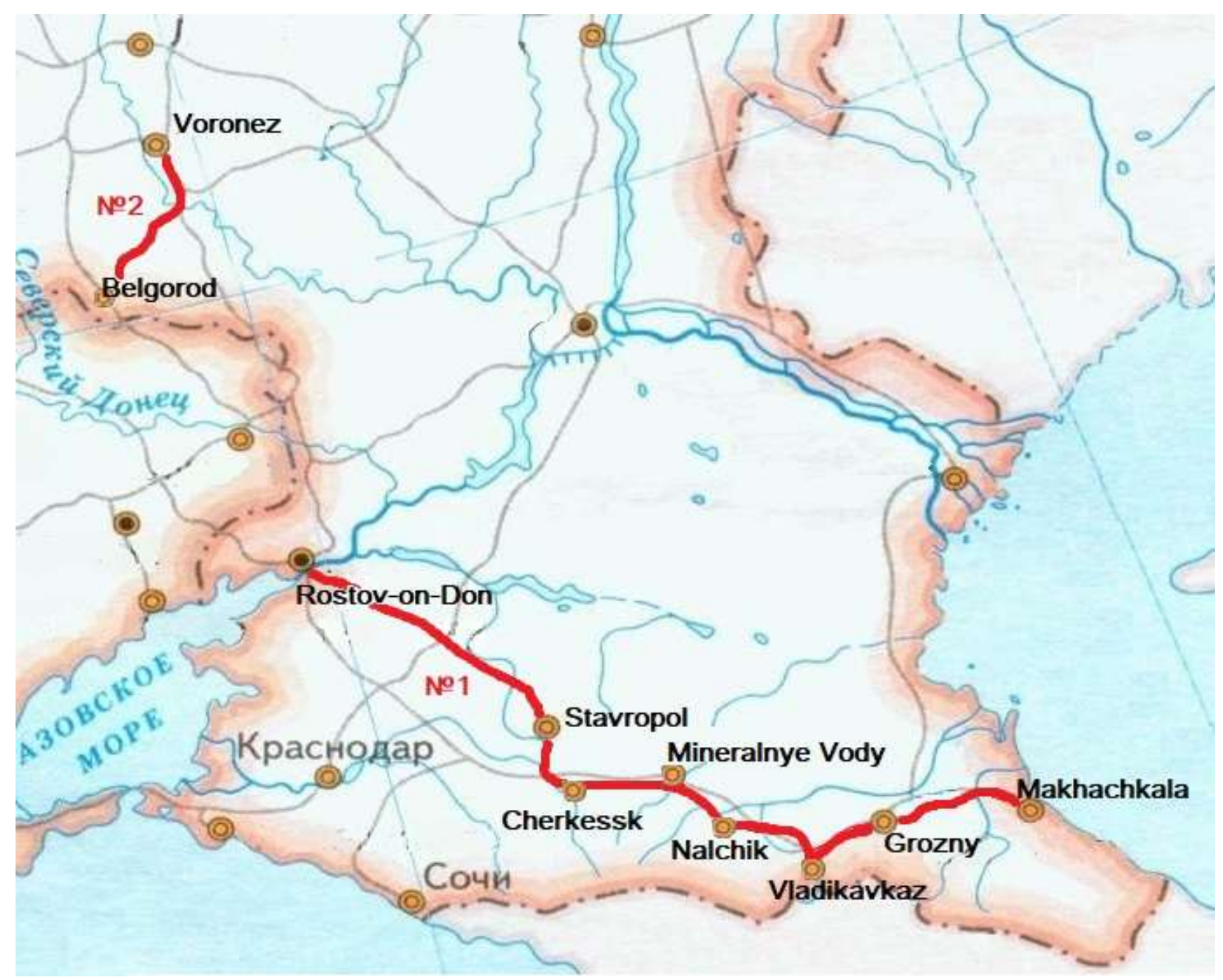

Figure 1. The survey route to check the oak lace bug presence in 2018.

№1 - route Rostov-on-Don - Makhachkala;№ 2 - route Voronezh - Belgorod. As a result, the bug was discovered in all checked cities (table 1).

Table 1. - Results discovering of C. arcuata in North Caucasus cities in 2018.

\begin{tabular}{lccc}
\hline $\begin{array}{l}\text { Location of the } \\
\text { survey (Name) }\end{array}$ & Coordinates & $\begin{array}{c}\text { Type of urban } \\
\text { landscape }\end{array}$ & $\begin{array}{c}\text { Number of individuals per 1 running } \\
\text { meter of a branch, pcs. } \\
\text { accounted trees adults egg clusters }\end{array}$ \\
\hline
\end{tabular}




\begin{tabular}{|c|c|c|c|c|c|}
\hline Rostov-on-Don & $\begin{array}{l}4^{\circ} 13^{\prime} 47^{\prime \prime} \mathrm{N} \\
39^{\circ} 44^{\prime} 43^{\prime \prime} \mathrm{E}\end{array}$ & Park & 3 & 1 & 1 \\
\hline Stavropol & $\begin{array}{l}45^{\circ} 2^{\prime} 49^{\prime \prime} \mathrm{N} \\
41^{\circ} 58^{\prime} 34^{\prime \prime} \mathrm{E}\end{array}$ & $\begin{array}{l}\text { Park and street } \\
\text { planted }\end{array}$ & 20 & 3 & 1 \\
\hline Cherkessk & $\begin{array}{c}44^{\circ} 14^{\prime} 6 " \mathrm{~N} \\
42^{\circ} 2^{\prime} 9^{\prime \prime} \mathrm{E}\end{array}$ & Park & 2 & 2 & 2 \\
\hline MineralnyeVody & $\begin{array}{c}44^{\circ} 12^{\prime} 36^{\prime \prime N} \\
43^{\circ} 7^{\prime} 50^{\prime \prime} \mathrm{E}\end{array}$ & Park & 5 & 2 & 2 \\
\hline Nalchik & $\begin{array}{l}43^{\circ} 30^{\prime} 35^{\prime \prime} \mathrm{N} \\
43^{\circ} 38^{\prime} 22^{\prime \prime} \mathrm{E}\end{array}$ & Park & 3 & 108 & 38 \\
\hline Vladikavkaz & $\begin{array}{l}43^{\circ} 2^{\prime} 58^{\prime \prime} \mathrm{N} \\
44^{\circ} 39^{\prime} 52^{\prime \prime} \mathrm{E}\end{array}$ & Park & 4 & 2 & 2 \\
\hline Grozny & $\begin{array}{l}43^{\circ} 19^{\prime} 8 " \mathrm{~N} \\
45^{\circ} 41^{\prime} 55^{\prime \prime} \mathrm{E}\end{array}$ & Park & 7 & 2 & 1 \\
\hline Makhachkala & $\begin{array}{c}42^{\circ} 58^{\prime} 54 " \mathrm{~N} \\
47^{\circ} 30^{\prime} 7 " \mathrm{E}\end{array}$ & Park & 6 & 3 & 1 \\
\hline
\end{tabular}

During the survey route, a reconnaissance assessment of the degree of damage caused to natural oak trees in the fall of 2018 was also carried out. The results show that two years after the first detection of the $C$. arcuata for already damaged oak trees in the Krasnodar Krai, the oak lace bug covered a distance of more than $700 \mathrm{~km}$. Moreover, it was visually determined that the oak trees of Karachay-Cherkessia and Kabardino-Balkaria were damaged as much as the oak trees of the Krasnodar Krai and Adygea Republic.

Such a result allows us to say with a great confidence that the discovery in 2015 of $C$. arcuata in the Krasnodar Krai occurred a few years later than its real introduction into the region. Apparently, for the first time in Russia, the bug appeared no later than 2010-2011, but was noticed only when first alarmingly high oak damage was, as a result of the outbreak mass breeding. When the forest protection service could no longer fail to notice visible changes in the condition of oak crowns [5]. Also, Martynov V.V. and Nikulina T.V. [6] discovered C. arcuata not due to the first found individuals bugs, but due to existing damage trees in the Stavropol Krai. Despite this, official information from the Federal Forestry Agency and Federal Service for Veterinary and Phytosanitary Surveillance about the identification of $C$. arcuata in Russia is still missing.

The second search surveys to check the presence of $C$. arcuata on oaks were northerly, on the territory of Voronezh and Belgorod (№2) (Figure 1). The bug was not discovered then.

However, currently there is information $[7,8]$ about the discovery of $C$. arcuata in Voronezh. The continued expansion of the secondary (invasion) range of the oak lace bug throughout Russia in the near future will lead to its appearance in the floodplain oak forests of the Don, Volga and their tributaries, which will lead to a deterioration in the condition of these woodlands.

Host plants of the oak lace bug are essentially genus Oak (Quercus). The main host plants in the pest's native range are limited to Section Quercus - «white oaks» (for example Quercus alba) and close North American species of this genus [9]. Data on the damage other genera and families plants are extremely contradictory. This is primarily due to the fact that adult bugs can be located on a variety of plants. At the same time, bugs can lay eggs on these plants, however, as laboratory studies have shown [10], the actual possibility of the development of bugs on certain plants often does not correspond to the field observations given in the publications. Thus, the list of pest host plants requires clarification.

In a laboratory studyin Europe, the most nymphs C. arcuata $(>50 \%)$ reached the adult stage on: Quercus robur, Q. pubescens Willd., Q. petraea (Mattuschka) Liebl., Q. cerris L., also on non-oak plants: Rubu sulmifolius Schott. and R. ideaus L.

The pest can feed on non-oak host plants, but nymphs can't develop successfully on: Castanea sativa Mill., Rosa canina L. Rubus caesius L. (less than $25 \%$ of larvae reached the adult stage) [10]. 
Publications [11,12] indicate the presence of oak lace bug on a wide range of other plants, including a number of species of the genus Oak, as well as Elm, Maple, Robinia, Cherry, Apple Tree, etc. More thorough scientific researches or laboratory study are needed to confirm these plants as the main hosts on which the bug reached the adult stage and can cause significant damage to them.

In Russia studies have shown that, the bug most severely damages the foliage of pedunculate oak $Q$. robur and chestnut-leaved oak Q. castaneifolia, but also some other species [13] (Table 2).

Table 2. Host plants oak lace bug Corythucha arcuata.

\begin{tabular}{|c|c|c|c|}
\hline Name & Damage & Location & Reference \\
\hline $\begin{array}{c}\text { Quercus robur } \\
Q . \text { petraea } \\
Q . \text { cerris } \\
Q . \text { frainetto }\end{array}$ & severe damage to foliage & $\begin{array}{l}\text { several European } \\
\text { countries }\end{array}$ & Csóka et. al., 2020 \\
\hline $\begin{array}{c}Q . \text { pubescens } \\
Q . \text { robur } \\
Q . \text { petrea } \\
Q . \text { cerris } \\
Q . \text { hartwissiana } \\
Q . \text { castaneifolia }\end{array}$ & $\begin{array}{l}\text { very severe damage to } \\
\text { foliage }\end{array}$ & $\begin{array}{l}\text { everywhere in the } \\
\text { invasive range in Russia }\end{array}$ & $\begin{array}{c}\text { Гниненко и др., } \\
2020\end{array}$ \\
\hline
\end{tabular}

Despite the fact that the oak lace bug has been damaging oak trees in Europe for more than 20 years and in Russia for almost 10 years, it is impossible to answer simply the question of the level of its harm. Currently, there is no information about the death of oak as a result of chlorotic discoloration and desiccation of leaves. There is no doubt that bug damage weakens trees, but how much these damages are detrimental to the affected trees remains unclear. It is considered that primarily due to the damage caused, the acorn crop decreases.

Nowadays there is no information in Russia that as a result of damage caused by bugs for several years, significant changes in the sanitary condition of oak trees have occurred. It should be believed that a systematic scientific study processes of the feeding by sucking fluids from plants' photosynthetic tissues will make it possible to reasonably determine the fate of damaged trees in the coming years.

\section{Conclusion}

Despite the fact that the oak lace bug was first discovered in 2015 in Russia, the one could introduce in the Krasnodar Krai before that, in 2010-2011.Since that time, it rapidly spread on oak trees and landscaping oak plantings in southern Russia from Rostov-onDon to Makhachkala, occupying the territory from the Black coast to the coast of the Caspian Sea.

More severe damages to oaks are currently being inflicted on the territory of the entire Krasnodar Krai and the republics of Adygea, Karachay-Cherkessia and KabardinoBalkaria. Less severe damages are caused in the Stavropol Krai, as well as in the republics of North Ossetia, Ingushetia, Chechnya and Dagestan.

At present, the question of the consequences of many years of damage to oak trees remains open.

\section{References}

1. Bernardinelli, I. Distribution of the oak lace bug Corythucha arcuata (Say) in northern Italy (Heteroptera Tingidae). Redia., 2000, LXXXIII, pp. 157-162.

2. Mutun S. First report of the oak lace bug, Corythucha arcuata (Say, 1832) (Heteroptera: Tingidae) from Bolu, Turkey / Isr. J. Zool. 49, 2003, pp. 323-324.

3. Gninenko Yu.I., Khegay I.V., Vasilieva U.A. Oak lace bug - new dangerous invader in the forests of Russia. Plant Health. Research and Practice. Moscow. December 2017. pp. 9-15. [in Russian and English] 
4. Shchurov V.I., Skvortsov M.M. 2016 Dispersal of the oak lace bug Corythucha arcuata (Say, 1832) in the deciduous forests of the Krasnodar Territory and the Republic of Adygea becoming pandemic. Available from: http://www.czl23.ru/news.php?extend.202. (last accessed June, 2021) in Russian.

5. Gninenko Yu.I., Chernova U.A., Gimranov R.I, Kchegai I.V. Corythucha arcuata is expanding its range on the territory of Russia / Zashchita i karantin rastenij, 2020, № 10. - pp. 37-39. (in Russian).

6. Martynov V.V., Nikulina T.V First finding of Corythucha arcuata (Say, 1832) (Hemiptera: Tingidae) in Stavropol region. Results and prospects for the development of entomology in Eastern Europe. Collection of articles of the III International Scientific and Practical Conference dedicated to the memory of Vadim Anatolyevich Tsinkevich (1971-2018) November 19-21, 2019, Minsk. Minsk, publisher A.N. Varaksin, 2019; pp. 245-247. (in Russian).

7. Blyummer A.G. North-ward expansion of distribution borders of the oak lace bug Corythucha arcuata (Say, 1832) (Heteroptera: Tingidae) in the European part of Russia: anthropogenic introduction into Voronezh Province/ Dendrobiontnye bespozvonochnye zhivotnye i griby i ih rol' v lesnyh ekosistemah (XI CHteniya pamyati O.A. Kataeva). SPb., 2020; pp. 90-91. (in Russian).

8. Blyummer A.G., Korobeynikova L.A. Chronology of the invasive range formation of the oak lace bug Corythucha arcuata (Say, 1832) (Heteroptera: Tingidae) in Krasnodar Region, Russia / Dendrobiontnye bespozvonochnye zhivotnye i griby i ih rol' v lesnyh ekosistemah (XI CHteniya pamyati O.A. Kataeva). SPb., 2020; pp. 92 - 93. (in Russian).

9. Csóka G., Hirka A., Mutun S., Glavendekic M., Mikó Á., Szőcs L. Paulin M., Eötvös C.B., Gáspár C., Csepelényi M., Szénási Á., Franjevic M., Gninenko Y., Dautbašić M., Mujezinovic O., Zubrik M., Netoiu C.; Buzatu A.; Bălăcenoiu F., Jurc M., Jurc D., Bernardinelli I., Streito; Avtzis D.; Hrašovec B. Spread and potential host range of the invasive oak lace bug [Corythucha arcuata (Say, 1832) - Heteroptera: Tingidae] in Eurasia. // Agricultural and Forest Entomology, 2020, v. 22 (1); pp. 61-74.

10. Bernardinelli, I.; Zandigiacomo, P. (2000) First record of the oak lace bug Corythucha arcuata (Say) (Heteroptera, Tingidae) in Europe. Informatore Fitopatologico, 2000, no. 12, pp. 47-49.

11. Neimorovets V.V., Shchurov V.I., Bondarenko A.S., Skvortsov M.M., Konstantinov F.V. 2017. First documented outbreak and new data on the distribution of Corythucha arcuata (Say, 1832) (Hemiptera: Tingidae) in Russia // Acta ZoologicaBulgarica. Suppl. 9; pp. 139-142.

12. Borisov B.A., Karpun N.N., Bibin A. R., Grabenko Ye. A., Shiryaeva N.V., Lyanguzov M.Ye. New data on trophic relations of the invasive oak lace bu g Corythucha arcuata (Heteroptera: Tingidae) in the Krasnodar region and in the Repub lic of Adygea based on the research findings for the year 2018 /Subtropicheskoe i dekorativnoe sadovodstvo (67) Zashchita Rastenij. 2018. Page 188-203. (in Russian).

13. Shchurov V.I., Zamotajlov A.S., Bondarenko A.S., Shchurova A.V., Skvortsov M.M., Glushchenko L.S. The oak lace bug Corythucha arcuata (Say, 1832) (Heteroptera: Tingidae) in the Northwestern Caucasus: phenology, biology, monitoring of the territorial expansion, and harmfulness. Izvestia Sankt-Peterburgskoj Lesotehniceskoj Akademii, 2019, is. 228, pp. 58-87 (in Russian with English summary). 